\title{
Isolation and Characterization of a Mutant of Escherichia coli K12 Synthesizing DNA Polymerase I and Endonuclease I Constitutively
}

\author{
By S. I. AHMAD, ${ }^{1 *}$ A. ATKINSON ${ }^{2}$ AND A. EISENSTARK ${ }^{3}$ \\ 1 Department of Life Sciences, Trent Polytechnic, Burton Street, \\ Nottingham NG1 $4 B U$ \\ 2 Diagnostic Reagents Laboratory, PHLS Centre for Applied Microbiology \\ and Research, Porton, Wiltshire SP4 0JG \\ 3 Division of Biological Sciences, 105 Tucker Hall, \\ University of Missouri, Columbia, Missouri 65211, U.S.A.
}

(Received 5 July 1979; revised 28 September 1979)

\begin{abstract}
A mutant of Escherichia coli $\mathrm{K} 12$, highly resistant to ultraviolet radiation, has been isolated. Preliminary tests show that this mutant is also resistant to mitomycin $\mathrm{C}$, nalidixic acid, fluorouracil and thymineless death. The mutant strain apparently repairs its damaged DNA more efficiently than wild-type $E$. coli $\mathrm{K} 12$ strains and, to do so, constitutively produces 35 times more DNA polymerase I and 12 times more endonuclease $I$ than the wild-type strain.
\end{abstract}

\section{INTRODUCTION}

Wild-type strains of Escherichia coli are relatively resistant to ultraviolet radiation (u.v.) since they have several DNA repair mechanisms (for review, see Grossman et al., 1975). Some R factors and colicin factors may also confer partial protection to their host cell, $E$. coli, against the bactericidal effect of u.v. (Siccardi, 1969). Although a mutant strain, $E$. coli $\mathrm{P} 6$ derived from $E$. coli $\mathrm{B} / \mathrm{r}$, was found to have enhanced resistance to X-rays (Zelle \& Ogg, 1957), there is no report of any $E$. coli $\mathrm{K} 12$ mutant with increased resistance to u.v. The X-ray resistant cells were larger than the parent strain cells, weighed about three times more, contained approximately three times more DNA and RNA, and were resistant to phage T1 (Zelle \& Ogg, 1957). Genetic analysis of this P6 strain showed that a single mutation was responsible for the pleiotropic phenotype (Kvetkas et al., 1970).

In this paper we report the isolation and preliminary characterization of a mutant of $E$. coli $\mathrm{K} 12$ with enhanced resistance to u.v. killing, thymineless death, mitomycin $\mathrm{C}$, nalidixic acid and fluorouracil compared with its parent strain. It would appear that the mutant strain has gained these abilities as a result of synthesizing DNA polymerase I and endonuclease I constitutively.

\section{METHODS}

Bacterial strains. Escherichia coli Hfr KL14, AB1157 (Bachmann, 1972), SA236 (u.v. super-resistant derivative of KL14), SA229 (thy derivative of AB1157) and SA242 (u.v. super-resistant derivative of SA229) were used.

Isolation of u.v. super-resistant (UVS-r) mutant. The mutant strain SA236 was isolated from Hfr KL14 by exposing bacteria (approx. $5 \times 10^{7}$ per plate) on nutrient agar to a u.v. dose of $180 \mathrm{~J} \mathrm{~m}^{-2}$ followed by 
analysis of survivors for u.v. resistance. Strain SA236 tolerated a heavier dose of u.v. than its parent strain, KL14.

The UVS-r character was transferred from strain SA236 to SA229 by conjugation selecting for His recombinants.

Characterization of UVS-r mutant. Strains KL14 (wild-type) and SA236 (UVS-r) were tested qualitatively for resistance to mitomycin C (MC), nalidixic acid (NAL), fluorouracil (FU), hydrogen peroxide $\left(\mathrm{H}_{2} \mathrm{O}_{2}\right)$ and chloramphenicol (CAP). This was done by adding $0.5 \mathrm{ml}$ of freshly grown bacterial cultures in nutrient broth (each having the same $A_{450}$ ) to $4.5 \mathrm{ml}$ of $0.6 \%$ nutrient agar and then overlaying the bacteria on nutrient agar plates. Analytical discs (12.7 mm diam.; Carl Schleicher \& Schüll Co., Dassel, Germany) were then impregnated with solutions of the inhibitors (MC, FU and CAP, $1 \mathrm{mg} \mathrm{ml}^{-1}$; NAL, $5 \mathrm{mg} \mathrm{ml}^{-1}$; $\mathrm{H}_{2} \mathrm{O}_{2}, 10 \mathrm{mg} \mathrm{ml}^{-1}$ ) and placed on the bacterial lawn. After overnight incubation, the inhibition zones were measured.

Measurement of thymineless death. The rate of thymineless death was measured as described earlier (Ahmad, 1980).

Enzyme assays. For enzyme analysis, freshly grown bacteria in double-strength nutrient broth were washed with $50 \mathrm{~mm}-\mathrm{Tris} / \mathrm{HCl}, \mathrm{pH} 7 \cdot 5$, containing $1 \mathrm{mM}-\mathrm{MgCl}_{2}$ and broken by sonication $(20 \mathrm{kHz}, 5 \mathrm{~A}$, $4 \times 1 \mathrm{~min}$ in ice) at $4 \mathrm{~g}$ wet wt packed cells per $20 \mathrm{ml}$ buffer $\mathrm{A}$ [ $50 \mathrm{~mm}$-Tris/ $\mathrm{HCl}, \mathrm{pH} \mathrm{7.5}$, containing $1 \mathrm{~mm}-$ $\mathrm{MgCl}_{2}, 0.5 \mathrm{~mm}-\mathrm{Na}_{2} \mathrm{EDTA}, 10 \mathrm{mM}$-2-mercaptoethanol, $0.1 \mathrm{~mm}$-phenylmethylsulphonyl fluoride and $5 \%(\mathrm{w} / \mathrm{v})$ glycerol]. Following centrifugation at $40000 \mathrm{~g}$ for $1 \mathrm{~h}$ at $4{ }^{\circ} \mathrm{C}$ the clarified cell extracts were dialysed against $10 \mathrm{~mm}$-potassium phosphate, $\mathrm{pH} 7 \cdot 5$, and analysed for enzyme activities as below, and for protein using Lowry's method.

DNA polymerase I was assayed using 'activated' calf thymus DNA as described by Englund (1971); tRNA $\left(40 \mu \mathrm{g} \mathrm{ml}^{-1}\right)$ was added to inhibit endonuclease I activity. Exonuclease I and exonuclease III were assayed as described by Lehman (1966) and by the phosphatase assay of Richardson (1966), respectively, with tRNA ( $\left.40 \mu \mathrm{g} \mathrm{ml}^{-1}\right)$ added to inhibit endonuclease I activity in both assays. DNA ligase was assayed by adenylation essentially as described by Gellert (1971) after dialysis against buffer A to remove endogenous NAD. Endonuclease I was assayed essentially as described by De Waard \& Lehman (1966), the activity being taken as the difference between the value for the assay including RNAase and that excluding RNAase but including tRNA $\left(40 \mu \mathrm{g} \mathrm{ml}^{-1}\right)$. Exonuclease Il activity was assayed as described by Obinata \& Mijuno (1968) but using $p$-nitrophenylthymidine-5-phosphate as substrate. In all cases activity is expressed as units (mg protein) $)^{-1}$ and units are as described in the assay references. tRNA was included in the assays for DNA polymerase I, exonuclease I and exonuclease III to eliminate the effect that different levels of endonuclease I in the two strains (see Table 1) might have on the assay for these enzymes.

\section{RESULTS AND DISCUSSION}

After exposure to a u.v. dose of $180 \mathrm{~J} \mathrm{~m}^{-2}$ (time of exposure, $2 \mathrm{~min}$ ), $0.0067^{\circ} \%$ of the wild-type and $1.85 \%$ of UVS-r cells survived (Fig. 1). The measured Dose Enhancement Factor (DEF) value (Hartman \& Eisenstark, 1978) of the resistant mutant was 1.64. Further analysis of the mutant strain showed that it had lost the ability to grow on minimal medium on which the parent strain could grow. Upon testing for its new nutritional requirements, no amino acids and/or vitamins could be found to satisfy its growth needs; instead, growth occurred only on complex media such as nutrient agar or broth.

Enzyme analysis of the cell extracts of both KL14 (wild-type) and SA236 (UVS-r) showed significant differences in the activities of enzymes associated with nucleic acid

Table 1. DNA repair enzyme activities in strains KL14 (wild-type) and SA236 (UVS-r)

Enzyme units are as used by previous authors (see Methods).

Enzyme

DNA polymerase I

Exonuclease I

Exonuclease II

Exonuclease III

Endonuclease I

DNA ligase
Enzyme activity [units (mg protein) ${ }^{-1}$ ]

\begin{tabular}{cc}
\hline KL14 (wild-type) & SA236 (UVS-r) \\
$3 \cdot 2$ & $116 \cdot 0$ \\
$10 \cdot 7$ & $12 \cdot 2$ \\
$3 \cdot 8$ & $3 \cdot 3$ \\
$36 \cdot 0$ & $81 \cdot 0$ \\
$14 \cdot 0$ & $170 \cdot 0$ \\
$2 \cdot 2$ & $2 \cdot 0$
\end{tabular}




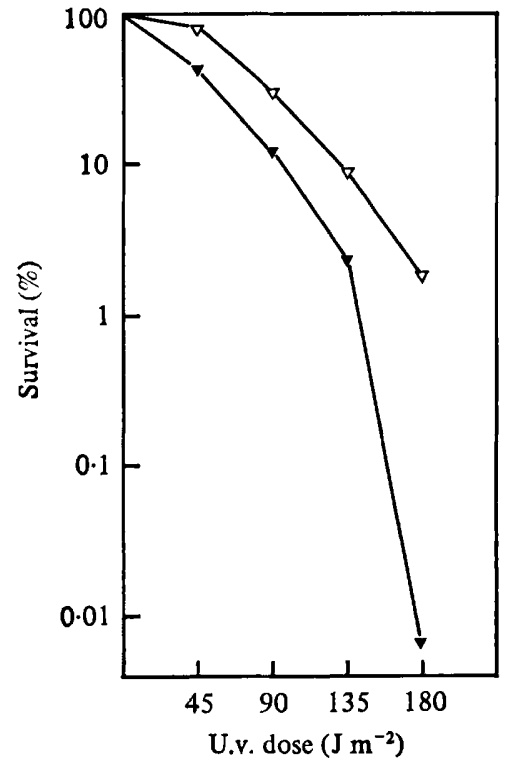

Fig. 1

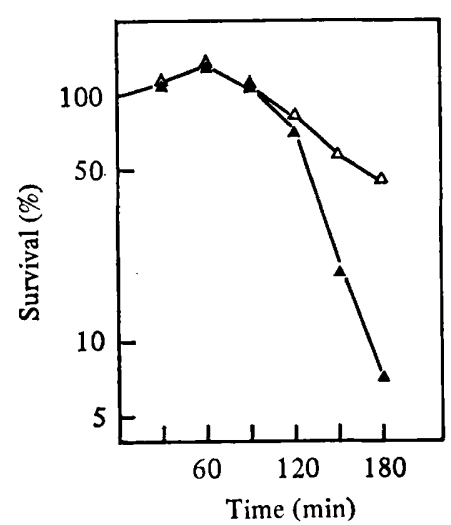

Fig. 2

Fig. 1. Survival of KL14 (wild-type) ( $\nabla)$ and SA236 (UVS-r) ( $\nabla)$ at various u.v. doses. Cultures in M9 salts medium (Clowes \& Hayes, 1968) were treated by superimposing exposures of $30 \mathrm{~s}$ $\left(45 \mathrm{~J} \mathrm{~m}^{-2}\right)$ each. After each $30 \mathrm{~s}$ exposure samples were removed, diluted and plated on nutrient agar.

Fig. 2. Thymineless death in SA242 (UVS-r) $(\triangle)$ and SA229 (wild-type) (A) strains.

Table 2. Inhibition of growth of strains KL14 (wild-type) and SA236 (UVS-r) by various agents

$\begin{array}{cccc}\text { Inhibitor* } & \text { Concn }\left(\mathrm{mg} \mathrm{ml}^{-1}\right) & \text { KL14 (wild-type) }_{\text {SA236 (UVS-r) }}^{\text {Zone of inhibition (mm) }} \\ \text { MC } & 1 & 22 & 18 \\ \text { NAL } & 5 & 37 & 32 \\ \text { FU } & 1 & 19 & \text { None } \\ \text { CAP } & 1 & 27 & 27 \\ \mathrm{H}_{2} \mathrm{O}_{2} & 10 & 19 & 19\end{array}$

* MC, Mitomycin C; NAL, nalidixic acid; FU, fluorouracil; CAP, chloramphenicol.

synthesis, metabolism and repair (Table 1). In the UVS-r strain, SA236, DNA polymerase I activity was increased 35-fold, endonuclease I activity was increased 12-fold and exonuclease III activity was increased 2 -fold compared with the wild-type strain, KL14. It is likely that the large elevation in both DNA polymerase I and endonuclease I activities in SA236 are two of the factors responsible for the super u.v. resistance of this strain, because constitutive levels of these enzymes should result in rapid and efficient repair of u.v.damaged DNA. The activities of exonuclease I, exonuclease II and DNA ligase, on the other hand, remained unchanged.

The UVS-r strain, SA236, remained as sensitive as the wild-type, KL14, to CAP and $\mathrm{H}_{2} \mathrm{O}_{2}$, but was more resistant to FU, MC and NAL (Table 2). Since FU, MC, NAL, $\mathrm{H}_{2} \mathrm{O}_{2}$ and thymine starvation are known DNA damaging agents (Ananthaswamy \& Eisenstark, 1977; Cozzarelli, 1977; Nakayama \& Hanawalt, 1975) and since the mutant strain has simultaneously enhanced its resistance to most of these agents, it can be assumed that the 
mutant bacteria repair damaged DNA more efficiently than do the wild-type organisms. The lack of resistance to $\mathrm{H}_{2} \mathrm{O}_{2}$ may be because activity of DNA ligase in the mutant strain is no higher than in the wild-type parent strain, hence the single-strand DNA breaks induced by $\mathrm{H}_{2} \mathrm{O}_{2}$ (Ananthaswamy \& Eisenstark, 1977) are repaired no more efficiently.

To test the mutant strain for thymineless death, the putative UVS-r mutation(s) was first transferred by conjugation to a thy his strain, SA229, selecting for His ${ }^{+}$recombinants. One of the thy $h$ s $^{+}$derivatives, SA242, which showed enhanced resistance to u.v. killing (results not presented), was examined for tolerance to thymineless death. It may be seen (Fig. 2) that, in addition to UVS-r properties, strain SA242 was also more resistant to thymineless death than its recipient parent strain, SA229.

Measurement of the growth of SA229 (wild-type) and SA242 (UVS-r) in minimal synthetic medium (results not presented) and microscopic examination showed that the mutant strain did not differ from the wild-type parent strain either in growth rate or morphology. This is a distinct difference from the P6 X-ray resistant-strain described previously (Zelle \& Ogg, 1957). Further genetic analysis of the UVS-r strain is in progress.

This investigation was supported by USPH grant 2 RO1 FD00658 and the University of Missouri Graduate Research Council.

\section{REFERENCES}

Ahmad, S. I. (1980). Thymineless death in recombination deficient mutants of Escherichia coli. Zeitschrift für Naturforschung (in the Press).

Ananthaswamy, H. N. \& Eisenstark, A. (1977). Repair of hydrogen peroxide induced singlestrand breaks in Escherichia coli deoxyribonucleic acid. Journal of Bacteriology 130, 187-191.

BachmanN, B. J. (1972). Pedigree of some mutant strains of Escherichia coli K12. Bacteriological Reviews 36, 525-557.

Clowes, R. C. \& HAYES, W. (1968). Experiments in Microbial Genetics. Oxford: Blackwell Scientific Publications.

Cozzarelli, N. R. (1977). The mechanism of action of inhibitors of DNA synthesis. Annual Review of Biochemistry 46, 641-668.

DeWaARD. A.\&Lehman, I. R. (1966). Endonuclease I from Escherichia coli. In Procedures in Nucleic Acid Research, vol. 1, pp. 122-129. Edited by G. L. Cantoni \& D. R. Davies. New York: Academic Press.

Englund, P. T. (1971). DNA polymerase from Escherichia coli. In Procedures in Nucleic Acid Research, vol. 2, pp. 864-874. Edited by G. L. Cantoni \& D. R. Davies. New York: Academic Press.

Gellert, M. (1971). DNA ligase from E. coli. In Procedures in Nucleic Acid Research, vol. 2, pp. 875-888. Edited by G. L. Cantoni \& D. R. Davies. New York: Academic Press.

Grossman, L., Braun, A., Feldberg, R. \& Mahler, I. (1975). Enzymatic repair of DNA. Annual Review of Biochemistry 44, 19-43.
Hartman, P. S., \& Eisenstark, A. (1978). Synergistic killing of Escherichia coli by near UV radiation and hydrogen peroxide: distinction between $\operatorname{rec} A$ repairable damage. Journal of Bacteriology 133, 769-774.

KvetKas, M. J., KRISCH, R. E. \& Zelle, M. R. (1970). Genetic analysis of a large cell radiationresistant strain of Escherichia coli. Journal of Bacteriology 103, 393-399.

LeHMAN, I. R. (1966). Exonuclease I (phosphodiesterase) from Escherichia coli. In Procedures in Nucleic Acid Research, vol. 1, pp. 203-211. Edited by G. L. Cantoni \& D. R. Davies. New York: Academic Press.

Nakayama, H. \& Hanawalt, P. (1975). Sedimentation analysis of deoxyribonucleic acid from thymine starved Escherichia coli. Journal of Bacteriology 121, 537-547.

Obinata, M. \& Mijuno, D. (1968). Intracellular localisation of DNAase in Escherichia coli. Biochimica et biophysica acta 155, 98-106.

Richardson, C. C. (1966). Exonuclease III from Escherichia coli. In Procedures in Nucleic Acid Research, vol. 1, pp. 212-223. Edited by G. L. Cantoni \& D. R. Davies. New York: Academic Press.

SicCARdI, A. G. (1969). Effect of R factors and other plasmids on ultraviolet susceptibility and host cell reactivation property of Escherichia coli. Journal of Bacteriology 100, 337-346.

Zelle, M. R. \& OGG, J. E. (1957). Radiation resistance and genetic segregation in a large cell possibly a polyploid strain of Escherichia coli. Journal of Bacteriology 74, 485-493. 